\title{
EFFECT OF DIETARY EDUCATION MANAGEMENT ON SELF- MANAGEMENT AMONG ELDERLY WITH OSTEOARTHRITIS
}

\author{
Devi Hairina Lestari 1), Rita Kartika Sari²), Nurullya Rachma3) \\ ${ }^{1)}$ Department of Nursing, Faculty of Medicine, Universitas Diponegoro \\ 2)Academy of Nursing Intan Martapura, Semarang \\ 3)Faculty of Medicine, Universitas Diponegoro, Semarang
}

\begin{abstract}
Background: Osteoarthritis (OA) is a classic age-related disorder. It is often described as a chronic degenerative disease. Osteoarthritis most commonly affects the hands, knees, hips and spine with knee osteoarthritis representing a major cause of pain and activity limitation. The importance of OA management as part of the care of individuals, especially among the elderly cannot be overlooked. This study aimed to analyze the effect of dietary education management on selfmanagement among elderly with osteoarthritis.

Subjects and Method: This was a quasi-experiment before and after with control group design. The study was conducted at community health center (Puskesmas) Padangsari, Semarang, Central Java. A sample of 88 elderlies was selected for this study. The dependent variable was self-management. The independent variable was dietary education management. The intervention was an educational packet of dietary education management for 4 times in a week. The data were collected by questionnaire before and after training and tested by Wilcoxon test.

Results: Score of self-management in the elderly receiving dietary education management was higher after the intervention (Mean=32.68) than before the intervention (Mean=24.34), and it was statistically significant. Change in score of self-management in the control group before and after the intervention was not statistically significant.

Conclusion: Dietary education management increases self-management among elderly with osteoarthritis.
\end{abstract}

Keywords: dietary education management, self-management, osteoarthritis

Correspondence:

Devi Hairina Lestari. Department of Nursing, Faculty of Medicine, Universitas Diponegoro, Semarang, Central Java. Email: devihairina89@hotmail.com. Mobile: o81347665678.

The 5th International Conference on Public Health

Best Western Premier Hotel, Solo, Indonesia, February 13-14, 2019 | 161 https://doi.org/10.26911/theicph.2019.02.06 